\title{
スペクトロメーターオフセット関数によるオージェ電子 分光法における簡易エネルギー軸較正方法
}

\author{
藤 田大介・吉原一紘 \\ 金属材料技術研究所③05 つくば市千現 1-2-1 \\ (1993 年 4 月 15 日受付, 1993 年 5 月 20 日掲載決定)
}

\section{A New and Practical Energy Calibration Method Using Spectrometer Offset Function in Auger Electron Spectroscopy}

\author{
Daisuke Fujita and Kazuhiro Yoshinara \\ National Research Institute for Metals \\ 1-2-1 Sengen, Tsukuba 305
}

(Received April 15, 1993 : Accepted May 20, 1993)

\begin{abstract}
A practical and simple calibration procedure for determining the energy scale in Auger electron spectroscopy (AES) by using a newly developed idea of a spectrometer offset function is proposed here. This method enables transformation of the uncalibrated energy scale to be the calibrated and Fermi-level-referenced ones. The reliability of the calibrated energy scale can be estimated by the standard error of least-square fitting of the spectrometer offset function to the experimental values. A round-robin test involving the different kinds of twelve spectrometers has been conducted to clarify the effectiveness of this calibration method. Compared with the Fermi-level-referenced kinetic energies of $\mathrm{Ni} \mathrm{L}_{3} \mathrm{VV}$ and $\mathrm{M}_{3} \mathrm{VV}$, the scatter of these calibration-corrected peak positions is found to be very low, amounting to $20 \sim 30 \%$ of the scatter of uncorrected values. It is also found that the spectrometers with the higher energy resolution tend to have the lower standard errors. These results clearly suggest that this procedure is very useful for the practical calibration of AES energy scale.
\end{abstract}

\section{1. 目 的}

オージェ電子分光法 (AES: Auger Electron Spectroscopy）に就いては従来からエネルギー軸の較正に関 する関心は，同様に電子のエネルギーの分光を行うX線 電子分光法 (XPS : X-ray Photoelectron Spectroscopy) に比べて低く，それ枕え得られたエネルギー值に対する 信賴性は著しく低かった。実際, 米国 ASTM E-42 委 員会のおこなったラウンドロビンテストの結果によれ ば, $\mathrm{Au}$ の $\mathrm{M}_{5} \mathrm{~N}_{6,7} \mathrm{~N}_{6,7}$ ピーク位置で測定機関間で最大

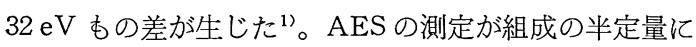
のみ重点を置き,データがその場限りで消耗されるよう な場合にはエネルギー軸の曖昧さの問題は比較的大きな 問題ではなかったかむしれない。しかし二つの理由から
現在ではこの問題は大きく取り上げられてきている。ひ とつは過去 10 年間の VAMAS-SCA 亿代表される表面 解析法の定量化, 標準化に対する進歩である2,3)。乙の 動きは当然のことながらエネルギー軸の標準化にも取 り組んでいる4,5)。あうひとつはファクターアナリシス (Factor Analysis) に代表される多变量解析手法がデー 夕解析に適用されはじめたてとである ${ }^{6,7)}$ 。乙の手法に は参照すべき標準スペクトルが必要であるため, 正確な スペクトルのデータベースを作るべきだというコンセン サスが得られつつある ${ }^{8}$ 。

てのような新しい動きに対応し，すでに M.P. Seah らは装置の厳密なエネルギー較正方法を開発し, 較正用 エネルギー值を提供している ${ }^{5)}$ 。彼らのおてなった較正 はエネルギー分解能が比較的高い CHA (Concentric 
Hemispherical Analyzer) 型分光器に対するあのである ことから, 得られたエネルギー軸の精度む高いと思われ る。さらに Seah らは $\mathrm{Au}, \mathrm{Ag}, \mathrm{Cu}$ のラウンドロビン 試験を行い，実験的に得られたエネルギー值に較正を 施すととによって各機関の報告したピーク位置の分散が ASTM の行ったそれに比較して〜15\% まで減少させら れることを示した ${ }^{9)}$ 。彼らの較正方法は電子の相対論的 効果まで考慮にいれた厳密なあのであるが，AES の データベースを構築する際には多数の機関からのさまざ まなレベルのデータを集める必要があるため, 実用的か つ簡易な較正方法や較正結果の報告仕様を標準化するこ とは意義のあることと思われる。

本論文では, 新しい簡易較正方法を提案し, その有用 性をラウンドロビン試験により調べたので報告する。本 研究はVAMAS-SCA の国内委員会における討議から 生まれたあのであり，それゆえ本ラウンドロビン試験は この研究会の枠内で行われた。なお，ことで提案する方 法はXPS においても同様に有用であると考えられ，運 動エネルギーが $2000 \mathrm{eV}$ 程度以下の一般の電子エネル ギー分光器すべてに適用できると思われる。

\section{2. スペクトロメーターオフセット関数}

従来から, AES においてはエネルギー軸の原点は真空 準位にとってきた。電子分光器は電子の運動エネルギー $E_{K}$ を自らのもつ真空準位 $E_{v, a}$ 加ら測定しているから である。しかし分光器の真空準位 $E_{v . a}$ は分光器ごとに 異なり, また経時変化がありうる。との結果, 同一試料 からのスペクトルでも異なった装置では異なったエネル ギー位置にピークが現れる可能性がある。このような理 由から,より普遍的なフェルミ準位 $E_{F}$ を基準に取るべ きであるとの指摘がなされており ${ }^{10)}$, 本論文であこの立 場をとるとととする。このようなエネルギー軸の関係を

Fig. 1 亿模式的に示す。この場合の試料は金属とする。 図中で試料に関する場合には添え字 $s$ (sample) が, 分 光器に関する場合には添え字 $a$ (analyzer) が各記号の 後に下ッキで添えられている。試料と分光器間は導体で 接続されているから試料のフェルミ準位 $E_{F, s}$ と分光器 のフェルミ順位 $E_{F, a}$ とは一致する $\left(=E_{F}\right)$ 。両者の仕事 関数 $\left(\Phi_{s}, \Phi_{a}\right)$ の差は接触電位差 $E_{c}$ である。試料のフェ ルミ準位基準の運動エネルギー $E_{K} . s$ は分光器の真空準 位基準の運動エネルギー $E_{K, a}$ とつぎの関係がある。

$$
E_{K, s}=E_{K, a}+\Phi_{a}
$$

この関係は XPS と AES の両方に成り立つ。XPS の 場合には既知のエネルギーhעのフォトンを入射し, 結 合エネルギー $E_{B}$ の内殼準位の電子を真空中へたたき出 す。その場合の光電子運動エネルギーと結合エネルギー

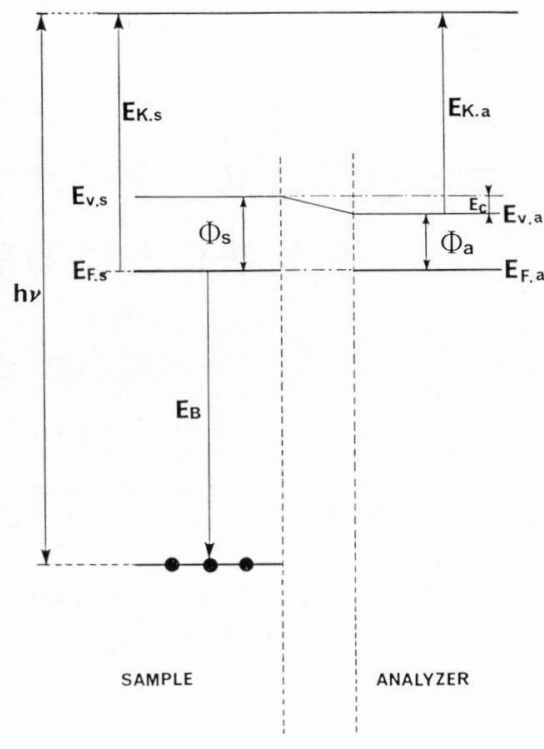

Fig. 1 Schematic diagram for the energy levels of emitted Auger electrons and X-ray photoelectrons which are measured by an electron spectrometer.

との関係を以下に示す。

$$
E_{B}=h \nu-E_{K, a}-\Phi_{a}=h \nu-E_{K, s}
$$

XPS では結合エネルギー $E_{B}$ の原点は試料のフェルミ 準位であり，また武料のフェルミ端は Ni などを用いて 実測するととができる。このととや，(2)式の関係が成 り立つことから, 試料フェルミ準位 $E_{F, s}$ を基準として 運動エネルギー $E_{K, s}$ や結合エネルギー $E_{B}$ を考える ことは, XPS の場合 AES と比較してより容易である。

CMA 型分光器の場合に多い真空準位基準の AES 測 定器の場合, (1) 式から測定器の示す真空準位のエネル ギー值とフェルミ準位のそれとの差は本来は分光器の仕 事関数 $\Phi_{a}$ に相当するべきである。しかしながら，実 際には測定電気回路系の䛊差などから, 多くの場合, こ の差は物理的な意味での分光器の仕事関数 $\Phi_{a}$ (Spectrometer Work Function) にはなっていないと考えられ る。CHA 型分光器の場合に多いフェルミ準位基準の AES 測定器でも, 設定フェルミ準位基準エネルギー值 と真のエネルギー值との間にはある程度の䛊差がある。 それゆえ, 分光器の型によらない実用的な較正方法を考 える場合, 測定器指示運動エネルギー軸 $\left(E_{0 b s}\right)$ と真の フェルミ準位基準のエネルギー軸 $\left(E_{K} . s\right)$ との差を問題 にすべきであり，との差のことをスペクトロメーター オフセット関数 (Spectrometer Offset Function) W と呼ぶととにする。これは測定器指示運動エネルギー軸 から真の軸（フェルミ準位基準）へ変換するための関数 
であり，AES にあ XPS にああてはまる概念である。 定義から，オフセット関数 W は測定装置から報告され たエネルギー $E_{o b s}$ の関数であるとする。すなわち,

$$
W\left(E_{o b s}\right)=E_{K . s}-E_{o b s}
$$

ここでは, 関数形としては次式で示すように 1 次関数形 で近似することにした。すなわち，測定系の指示値の誤 差としては定数分のオフセット Coのほかにェネルギー 軸走査における直線性の誤差も考慮に入れていることに なる。

$$
W\left(E_{o b s}\right)=C_{o}+C_{1} E_{o b s}
$$

なお，ここで 1 次式で近似したのは較正用の点が十分に 多くは提供されていないことによる。今後較正用のピー クが多く提供された場合には, より複雑な高次の多項式 関数を用いることも考えられる。

実験的に $W\left(E_{o b s}\right)$ を求める手順としては，まず既に エネルギー值が精度よく報告された $\mathrm{Au}, \mathrm{Cu}, \mathrm{Ag} の$ 純物質の指定のオージェピーク ( $\mathrm{Au} \mathrm{N}_{6,7} \mathrm{VV}, \mathrm{AuM}_{5}$ $\left.\mathrm{N}_{6,7} \mathrm{~N}_{6,7}, \mathrm{Cu} \mathrm{M} \mathrm{M}_{2,3} \mathrm{VV}, \mathrm{Cu} \mathrm{L} \mathrm{L}_{3} \mathrm{VV}, \mathrm{AgM}_{4} \mathrm{NN}\right)$ の位置 を測定する。てれらの較正值として M. P. Seah らに よって報告されたすの5) table 1 亿示す。つぎに得 られたピーク位置 $E_{o b s}$ と真のフェルミ準位基準の位置 $E_{K . s}$ とを図にプロットし, 最小二乗法を用いてフィッ ティングさせるととによって $W\left(E_{o b s}\right)$ の係数值を求め る。

Table 1 The first, second and third columns show the Auger transitions and the energy ranges to be measured, and the calibration kinetic energies which are Fermi level referenced, respectively. The stars (*) mean that the kinetic energy values for $\mathrm{Ni} \mathrm{M}_{3} \mathrm{VV}$

\begin{tabular}{|c|c|c|}
\hline $\begin{array}{l}\text { Sample/Auger } \\
\text { peak }\end{array}$ & $\begin{array}{c}\text { Energy range } \\
\text { to be measured } \\
E_{o b s} / \mathrm{eV}\end{array}$ & $\begin{array}{c}\text { Fermi level re- } \\
\text { ferenced Calibra- } \\
\text { tion energy } \\
E_{t_{\text {tue }}} / \mathrm{eV}\end{array}$ \\
\hline $\mathrm{Ag} \quad \mathrm{M}_{4} \mathrm{NN}$ & $335 \sim 365$ & 357.81 \\
\hline $\begin{array}{ll}\mathrm{Cu} & \mathrm{M}_{3} \mathrm{VV} \\
& \mathrm{M}_{2} \mathrm{VV}\end{array}$ & $50 \sim 85$ & $\begin{array}{l}61.16 \\
63.44\end{array}$ \\
\hline $\mathrm{Cu} \quad \mathrm{L}_{3} \mathrm{VV}$ & $900 \sim 930$ & 918.62 \\
\hline $\begin{array}{ll}\mathrm{Au} & \mathrm{N}_{7} \mathrm{VV} \\
& \mathrm{N}_{6} \mathrm{VV}\end{array}$ & $50 \sim 85$ & $\begin{array}{l}70.10 \\
72.21\end{array}$ \\
\hline $\mathrm{Au} \quad \mathrm{M}_{5} \mathrm{~N}_{6,7} \mathrm{~N}_{6,7}$ & $1995 \sim 2050$ & 2015.57 \\
\hline $\mathrm{Ni} \quad \mathrm{M}_{3} \mathrm{VV}$ & $45 \sim 80$ & $59.4(*)$ \\
\hline $\mathrm{Ni} \quad \mathrm{L}_{3} \mathrm{VV}$ & $830 \sim 860$ & $846.1(*)$ \\
\hline
\end{tabular}
and $\mathrm{L}_{3} \mathrm{VV}$ are not calibrated.

\section{3. ラゥンドロビン試験の実験方法}

参加機関は 11 機関, 測定に供した分光器は Table 2 に示すように 12 台であった。電子分光器の型としては, CHA が 2 メーカー 2 機種 2 台, CMA (Cylindrical Mirror Analyzer) が 2 メーカー6機種 10 台であった。 装置の報告する測定エネルギー軸は CHA の場合はフェ ルミ準位基準, CMA の場合はすべて真空準位基準であ った。測定モードとしては CHA の場合はFAT (Fixed Analyzer Transmission) むしくは CRR (Constant Retarding Ratio), CMA の場合はすべて $\Delta E / E=$ 一定 モードであった。

(1) 試料

較正に用いるエネルギ一軸較正用の標準試料として は，各機関でそれぞれ用意した純度 $99.9 \%$ 以上の $\mathrm{Au}$, $\mathrm{Ag}, \mathrm{Cu}$ の板状試料を用いた。また，乙のスペクトロ メーターオフセット関数を用いた簡易較正方法の精度を 調べるために純度 $99.9 \%$ 以上の $\mathrm{Ni}$ の板状試料を各機 関で参考試料として準備した。

（2）分光器位置調整

参加機関は必ず測定前に分光器の位置調整を $2 \sim 3$ $\mathrm{keV}$ の入射電子線の弾性散乱ピーク測定によりおてな い, 同時に分光器の実測エネルギー分解能を把握した。 分解能としては相対エネルギー分解能 $(\Delta E / E)$ であり, その定義は弾性散乱ピークの 1 階微分型スペクトルの極 大点と極小点との幅 $(\Delta E)$ をピークエネルギー（ゼロク ロス值：E) で除した值とした11)。

(3) オージェスペクトル測定

弾性散乱ピークによる電子分光器位置調整をおこなっ

Table 2 The types of respondee's instruments and their operation conditions for the round robin test of spectrometer offset function.

\begin{tabular}{r|c|c|c|c}
\hline No. & $\begin{array}{l}\text { Manufac- } \\
\text { turer- } \\
\text { Model } \\
\text { code }\end{array}$ & $\begin{array}{c}\text { Analyzer type- } \\
\text { referenced } \\
\text { level }\end{array}$ & $\begin{array}{c}\text { Energy } \\
\text { resolu- } \\
\text { tion }\end{array}$ & $\begin{array}{l}\text { Operation } \\
\text { mode }\end{array}$ \\
\hline 1 & $\mathrm{~A}-1$ & CHA-Fermi & $0.25 \mathrm{eV}$ & FAT \\
2 & $\mathrm{~B}-1$ & CHA-Fermi & $0.20 \%$ & CRR \\
3 & $\mathrm{~A}-2$ & CMA-Vacuum & $0.32 \%$ & $\Delta E / E=$ const. \\
4 & $\mathrm{~A}-3$ & CMA-Vacuum & $0.33 \%$ & $\Delta E / E=$ const. \\
5 & $\mathrm{~A}-3$ & CMA-Vacuum & $0.44 \%$ & $\Delta E / E=$ const. \\
6 & $\mathrm{~A}-4$ & CMA-Vacuum & $0.47 \%$ & $\Delta E / E=$ const. \\
7 & $\mathrm{C}-1$ & CMA-Vacuum & $0.56 \%$ & $\Delta E / E=$ const. \\
8 & $\mathrm{~A}-5$ & CMA-Vacuum & $0.60 \%$ & $\Delta E / E=$ const. \\
9 & $\mathrm{~A}-3$ & CMA-Vacuum & $0.68 \%$ & $\Delta E / E=$ const. \\
10 & $\mathrm{~A}-6$ & CMA-Vacuum & $0.78 \%$ & $\Delta E / E=$ const. \\
11 & $\mathrm{~A}-3$ & CMA-Vacuum & $0.83 \%$ & $\Delta E / E=$ const. \\
12 & $\mathrm{~A}-6$ & CMA-Vacuum & $1.0 \%$ & $\Delta E / E=$ const. \\
\hline
\end{tabular}


た後，各試料の測定前に希ガスイオンスパッタリングに よる表面清浄化を施した。つぎに, Table 1 亿示すよう な分光器指示エネルギー範囲の $\mathrm{N}(\mathrm{E})$ 型スペクトルを, 入射電子エネルギー $=5 \mathrm{keV}$, 測定ステップ $=0.1 \mathrm{eV}$ で 測定した。データはすべて計算機によるデジタル測定に より取り込み，各データをVAMAS フォーマット ${ }^{122} の$ ファイルとしてフロッピーディスクに収納し，金属材料 技術研究所に送付してもらった。Table 1 中に示した $\mathrm{Ni}$ のエネルギー值はフェルミ準位基準で測定された C. J. Powell らの值を参考值として載せたものであ る ${ }^{13)}$ 。彼らは XPS モードでフェルミ端を測定すること によってフェルミ準位基準のピーク位置を報告したのだ が, 較正された装置の值ではない。

\section{4. 結果および考察}

Table 2 に, 測定に供した電子分光器を弾性散乱ピー クから実測したエネルギー分解能が高い順に並べて示し た。それゆえ, 番号が小さいあのほど高分解能である。 特に No. 1 の装置は XPS 装置 (CHA 型電子分光器) に静電収束型電子銃を取り付けたむので, 最む高い分解 能(絶対分解能 $\Delta E=0.25 \mathrm{eV}$ ) で測定した。乙の装置 は, XPS としてすでに $\mathrm{MgK} \alpha$ 線を用いて, Au $4 \mathrm{f}_{7 / 2}$, $\mathrm{Cu} 3 \mathrm{p}, \quad \mathrm{CuL}_{3} \mathrm{MM}, \quad \mathrm{Cu} 2 \mathrm{p}_{3 / 2}, \quad \mathrm{Ag} 3 \mathrm{~d}_{5 / 2}, \quad \mathrm{AgM}_{4} \mathrm{NN}$ の

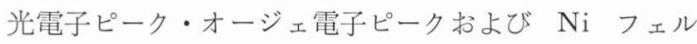
ミ端によってエネルギー軸を較正したものである。こ
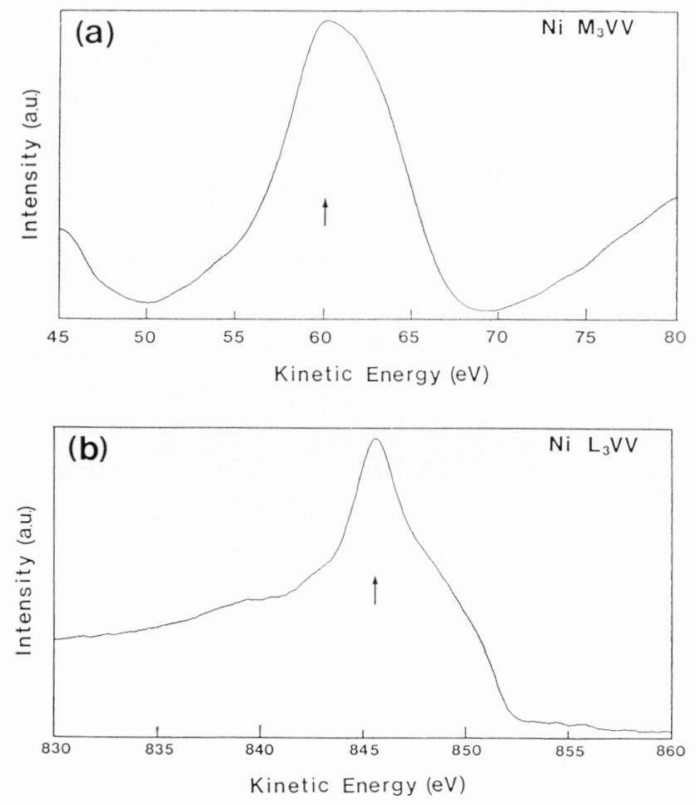

Fig. 2 Nickel Auger spectra measured by a CHA type spectrometer (No. 1). (a): $\mathrm{Ni} \mathrm{M}_{3} \mathrm{VV}$, (b) : $\mathrm{Ni} \mathrm{L}_{3} \mathrm{VV}$
の装置でフェルミ準位基準で測定された電子線励起の $\mathrm{NiM}_{3} \mathrm{VV}, \mathrm{L}_{3} \mathrm{VV}$ 各オージェスペクトルを Fig. 2 亿示 す。ピーク位置測定に用いた点を矢印で示した。Fig. 2 （a）に示した $\mathrm{NiM}_{3} \mathrm{VV}$ の場合, 全体としてのプロフ アイルは幅の広い構造を示しているが，ピーク近傍での 対称性はあまり良くないことがわかる。この理由は, こ のピークが厳密には $\mathrm{NiM}_{2,3} \mathrm{VV}$ であり, $\mathrm{M}_{2} \mathrm{VV}$ が高 エネルギー側に重畳しているためと考えられる。

Fig. 3 は，各機関から報告された $\mathrm{Niオージェピー}$ ク位置 $\left(\mathrm{M}_{3} \mathrm{VV}, \mathrm{L}_{3} \mathrm{VV}\right)$ をフェルミ準位基準の運動エネ ルギーに直してプロットしたものである。CMA の場合 は, 測定位置は真空準位基準で報告されるため, 便宜的 に標準真空準位 (standard vacuum level $=4.5 \mathrm{eV}$ ) を 用いて ${ }^{5)}$ ，仮のフェルミ準位基準へ直した。 $\mathrm{NiM}_{3} V V の$ 場合, 平均值は $60.7 \mathrm{eV}$, 標準偏差 $\sigma$ は $1.2 \mathrm{eV}$ であっ た。 $\mathrm{NiL}_{3} \mathrm{VV}$ の場合, 平均值は $847.4 \mathrm{eV}$, 標準偏差 $\sigma$ は $1.4 \mathrm{eV}$ であった。各データ点には Table 2 亿示し た対応する機種の番号を示した。データ点の分散は大き いが，ある規則性をあって分布していた。すなわち，図 中に示した傾き $45^{\circ}$ の直線近傍に約 $3 / 4$ の点が分布して いた。これは, 〜 75\% の点はある定数分のオフセット を測定エネルギー軸に加減するだけで，ほぼ同一のエネ ルギー值に収束するととを示している。

各機関の $\mathrm{Au}, \mathrm{Cu}, \mathrm{Ag}$ の各測定ピーク位置を最小二 乘法により 1 次式でフィッティングし, 各装置のスペク トロメーターオフセット関数 $W\left(E_{o b s}\right)$ を求めた。その 一例として No. 5 の CMA によって测定されたオフ

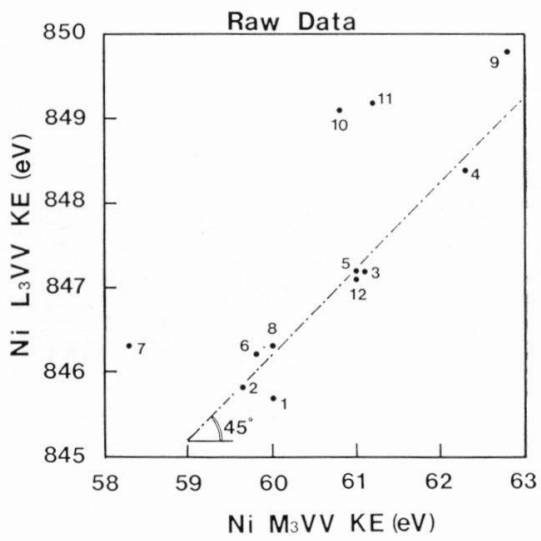

Fig. 3 Youden plot of the respondee's reported values for the Fermi level referenced kinetic energies of $\mathrm{Ni} \mathrm{L}_{3} \mathrm{VV}$ and $\mathrm{M}_{3} \mathrm{VV}$. In the case of CMA type spectrometers (No. 3 12), the vacuum level referenced values are transformed into the Fermi level referenced ones by using a standard vacuum level $(4.50 \mathrm{eV})$. 


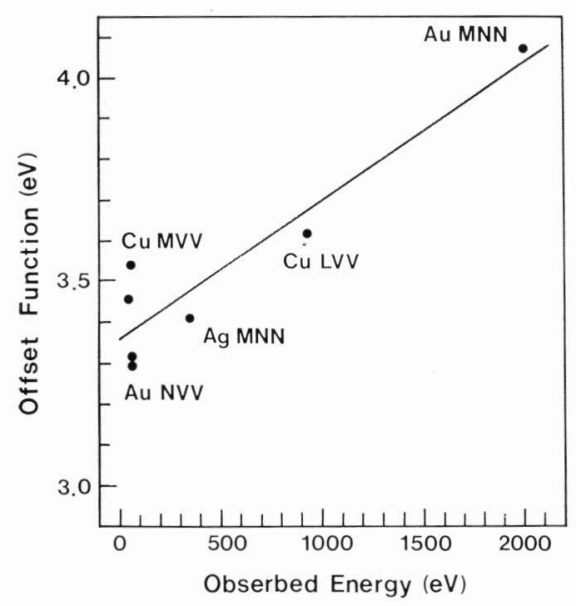

Fig. 4 The spectrometer offset function $W\left(E_{o b s}\right)$ for No. 5 spectrometer. Linear line is leastsquare fitted to the experimental offsets for the specified Auger peaks.

セット関数の結果去 Fig. 4 亿示す。CMA の場合, 定 数 $C$ 。は分光器の仕事関数 (標準值 $=4.5 \mathrm{eV}$ ) に相当す るはずであるが，実際には最小 2.2 最大 $6.2 \mathrm{eV}$ まで 分布していた。乙れは定数 $C$ 。 に分光器の仕事関数 $\Phi$ a という物理的な描像はもたせられないことを示してい る。

つぎに, 各機関から報告された $\mathrm{NiL}_{3} \mathrm{VV}, \mathrm{M}_{3} \mathrm{VV}$ ピー クエネルギー值 $E_{\text {obs }}$ 亿対して，おのおのの装置から得 られたオフセット関数 $W\left(E_{o b s}\right)$ を用いて補正を行った 結果をFig. 5 に示す。縦軸と横軸のスケールは Fig. 3 と同じにしてあるから，オフセット関数 W の利用に よって補正後のピークエネルギー值（フェルミ準位基 準) の分散が著しく小さくなったことがわかるだろう。 $\mathrm{NiM}_{3} \mathrm{VV}$ の場合, 標準偏差 $\sigma$ は $1.2 \mathrm{eV}$ から $0.2 \mathrm{eV}$ そ約1/6 になった。 $\mathrm{NiL}_{3} \mathrm{VV}$ の場合, 標準偏差 $\sigma$ は 1.4

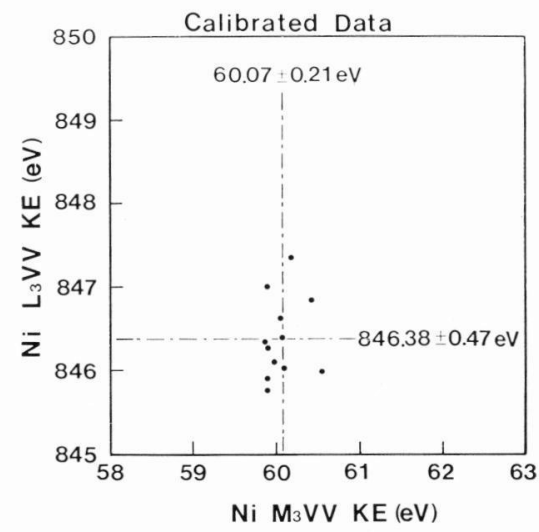

Fig. 5 Plot of the Auger peak positions calibrated by the spectrometer offset functions for $\mathrm{Ni} \mathrm{L}_{3} \mathrm{VV}$ against those for $\mathrm{Ni} \mathrm{M}_{3} \mathrm{VV}$.

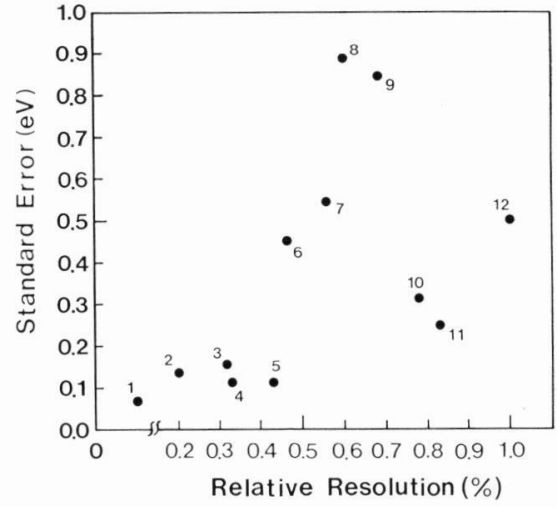

Fig. 6 Plot of the standard errors of least square fitting of spectrometer offset function against the relative energy resolutions of the respondee's spectrometers. Note that No. 1 is exceptional and has absolute resolution of 0.25 $\mathrm{eV}$.

$\mathrm{eV}$ から $0.5 \mathrm{eV}$ に約 $1 / 3$ になった。

また、データを詳細に検討した結果, 装置の分解能と 最小二乗法によるフィッティングの有効度との間には相 関性があることが判明した。フィッティングが適切に行 われたかどうかの判定は, 測定したデータ点を 1 次式に フィッティングする際の最小二乗法の計算から得られる 標準䛊差 (standard error) SE $E^{14)}$ という尺度を用いた。 これは次式で定義される。

$$
S E=\sqrt{\frac{S}{p-m-1}}
$$

ここで $S$ は残差の 2 乗和, $p$ はデータの個数, $m$ は多 項式の次数を示す。乙れはフィッティングした 1 次式と データ点との一致の度合いを示す尺度であり，值が小さ いほど良好なフィッティングが行われたてとを示してい る。

Fig. 6 は最小二乗近似で得られた各装置の標準誤差 SE と各分光器の相対エネルギー分解能との相関を示し たものである。No.1 の機種のみは FAT モード（絶 対分解能 $=0.25 \mathrm{eV}$ ) で測定されている。Fig. 6 より明 らかなように, 分解能が良い機種ほど標準誤差 SE あ 小さくなる傾向が認められる。分解能の良い上位 5 機種 はすべて標準䛊差が $0.2 \mathrm{eV}$ 以下に納まっていた。つま り，スペクトロメーターオフセット関数を用いる簡易較 正方法は分解能の良い分光器に, より有効であるといえ る。

Fig. 7 は補正された $\mathrm{Ni} \mathrm{L}$ VV ピーク位置と標準䛊 差 SE との関係を示したものである。全部のデータを 用いた場合では標準偏差 $\sigma=0.5 \mathrm{eV}$ であったが，比較 的高分解能機すなわち標準誤差 $S E$ か $0.2 \mathrm{eV}$ 以下の 


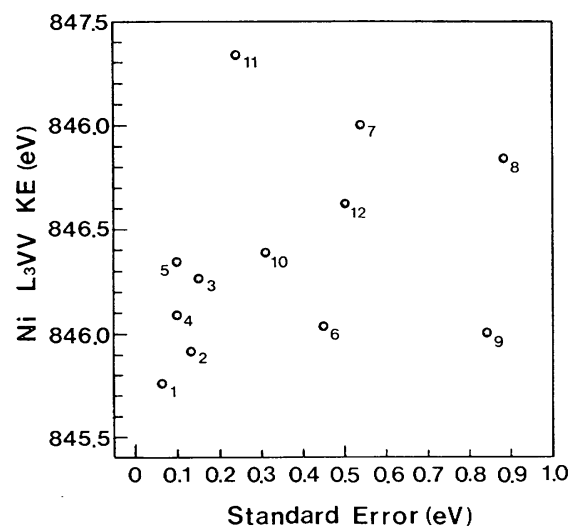

Fig. 7 Plot of the standard errors of least square fitting of spectrometer offset function against the calibrated Auger peak positions for $\mathrm{Ni} \mathrm{L}_{3} \mathrm{VV}$.

機種（No. 1 5) に限った場合， $\sigma=0.2 \mathrm{eV}$ とさらに データの分散を半減できるととがわかる。つぎにピーク 位置との関係を考える。 $\mathrm{NiL}_{3} \mathrm{VV}$ のピーク位置の全機 種の平均值は $846.4 \mathrm{eV}$ であったが, $S E$ が $0.2 \mathrm{eV}$ 以 下の機種のピーク位置の平均は $846.1 \mathrm{eV}$ と低エネル ギー側ヘシフトする。また， Fig. 7 のプロットを注意 深く見れば， $S E$ が大きくなるほど（分解能が大きくな るほど）ピーク位置が高くエネルギー側ヘシフトする傾 向にあるととがわかる。つまり, 装置のエネルギー分解 能と $\mathrm{NiL}_{3} \mathrm{VV}$ ピーク位置に相関があるといえる。Fig. 2(b) に示した $\mathrm{NiL}_{3} \mathrm{VV}$ のプロファイルは, 測定ピー ク位置の高エネルギー側にショルダーピークの構造があ る。このため, 装置のエネルギー分解能が低下すると 高エネルギー側のショルダーピークの影響を受けて測定 ピーク位置は高エネルギー側ヘシフトするすのと考えら れる。

同様に, 補正された $\mathrm{Ni} \mathrm{M}_{3} \mathrm{VV}$ ピーク位置と標準誤 差 $S E$ との関係を Fig. 8 亿示す。全部のデータを使用 した場合には標準偏差 $\sigma=0.2 \mathrm{eV}$ であったが，比較的 高分解能機（No. 1 5) 亿限った場合， $\sigma=0.1 \mathrm{eV}$ と半 分にできる。また， $\mathrm{NiM}_{3} \mathrm{VV}$ のピーク位置の全機種の 平均值は $60.1 \mathrm{eV}$ であったが, $S E$ が $0.2 \mathrm{eV}$ 以下の 機種に限定すると，ピーク位置の平均は $59.9 \mathrm{eV}$ と低 エネルギー側へシフトする。また，Fig. 8 のプロット から， $S E$ が大きくなるほど（分解能が大きくなるほど） ピーク位置が高エネルギー側ヘシフトする傾向にあるて とがわかる。つまり，乙の場合屯装置のエネルギー分解 能とピーク位置に相関があるといえる。乙れは，Fig. 2 (a) に示した $\mathrm{NiM}_{3} \mathrm{VV}$ のプロファイルのピーク近傍 での非対称性に起因すると考えられる。すなわち，ピー

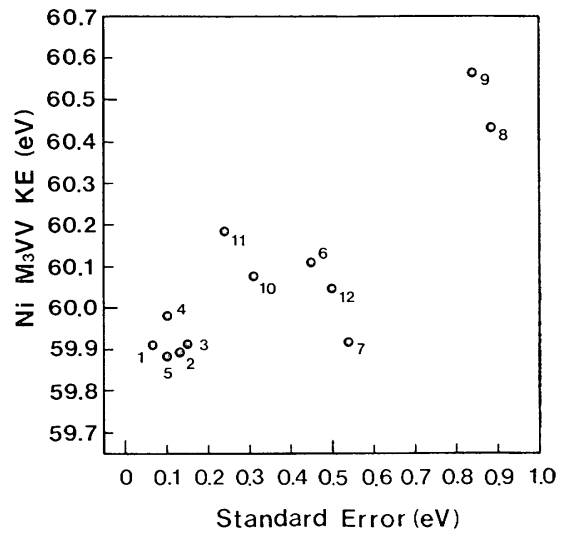

Fig. 8 Plot of the standard errors of least square fitting of spectrometer offset function against the calibrated Auger peak positions for $\mathrm{Ni} \mathrm{M}_{3} \mathrm{VV}$.

ク最大点は低分解能になるほどプロファイル全体として の重心位置，すなわち高エネルギー側へ若干シフトする あのと考えられる。

以上の結果は, 比較的高エネルギー分解能で標準誤差 の小さな装置を用いた場合，よりピーク位置に関する データのばらつきを小さくできるてと，すなわち，より 信頼性の高い測定ができるととを示している。

\section{5. まとめ}

厳密な装置の較正を行うことなく AES 装置のエネル ギー軸を較正するために，スペクトロメーターオフセッ 卜関数を用いた新しい実用的な簡易較正方法を考案し た。乙の簡易較正方法のラウンドロビン試験を行うとと によって，以下のような知見が得られた。

1) 真空準位基準の AES 装置の場合，より普遍的なつ ェルミ準位基準の運動エネルギー軸が得られる。

2) エネルギー軸の較正が行われ，その程度がある具体 的な精度（標準誤差 $S E$ ) で評価できる。

3） 12 台の AES 分光器で測定した $\mathrm{Ni} の \mathrm{~L}_{3} \mathrm{VV}$ およ び $\mathrm{M}_{3} \mathrm{VV}$ オージェピークのエネルギー位置の較正前後 の分散を比較した結果, 標準偏差 $\sigma$ で評価して 1/6 1/3 程度にピーク位置の分散を減少できることが判明した。

4) 相対エネルギー分解能の良い機種ほど標準誤差が小 さくなる傾向があり,データの分散をより小さくできる。

これらの結果から考えて，本方法は厳密な較正を簡略 化した較正方法であるが実用的な効果は大きいといえ る。また，簡易な手法であるため多くの機関で容易に実 行できることから，今後のスペクトルデータベースの構 築における標準の較正方法となると期待できる。なお， スペクトルデータベースに登録できるエネルギー軸の簡 
易較正結果の報告仕様としては現時点ではつぎのように 提案できる。すなわち, " $\mathrm{Au}, \mathrm{Cu}, \mathrm{Ag}$ の試料を用いて測 定分光器のスペクトロメーターオフセット関数 $W\left(E_{o b s}\right)$ を求め, その 2 個の係数 $\left(C_{o}, C_{1}\right)$ および標準誤差 $S E$ の三つのパラメーターを報告するとと。”

データベースに登録されるべきスペクトルは，そのス ペクトロメーターオフセット関数の有する標準誤差 $S E$ が小さいものほど望ましい。今回の結果から考えて，標 準誤差の上限としては $0.2 \mathrm{eV}$ 以下程度であろうと思わ れる。また, $S E$ の值によってデータのランク付けを 行うことも可能である。な扔，本方法はより多くの較正 ピーク位置を加えることによって信頼性の向上が望め る。上記の物質以外にも較正されたピークを提供するこ とが望ましいが，乙れは今後の課題といえる。

\section{謝 辞}

本研究を遂行するに当たり，有益な討論を賜わった VAMAS-SCA-JAPAN 委員会の各委員, ラウンドロ ビンテストに協力していただいた各機関の皆様に謝意を 表したいと思います。本ラウンドロビンにで協力いただ いた機関，研究者は以下のとおりです。

藤田大介 (著者, 金属材料技術研究所), 水野薰氏（新 日本製鉄 (株), 解析科学研究部), 名越正泰氏 (NKK (株), 鉄鋼研究所), 笠村秀明氏 (材料科学技術振興財 団), 本間芳和氏 (NTT (株), 境界領域研究所), 竹内 光一氏 (日本 IBM (株), 野州工場), 小泉光生氏 (三 菱マテリアル(株), 中央研究所), 塩沢一成氏(三井石 油化学工業(株), 新技術開発センター), 堂前和彦氏 ((株) 豊田中央研究所, ミク口解析研究室), 降屋幹男氏 (神奈川高度技術支援財団, 高度計測センター), 丸山達
哉氏（(株)富士ゼロックス，分析センター)，以上。

\section{文献}

1) C. J. Powell, N. F. Erickson and T.E. Madey: J. Electron Spectrosc. 25, 87 (1982).

2) C. J. Powell : Surf. Interface Anal. 11, 103 (1988).

3) C. J. Powell and M.P. Seah: J. Vac. Sci. Technol. A 8, 735 (1990).

4) M.T. Anthcny and M.P. Seah : Surf. Interface Anal. 6, 95 (1984)

5) M.P. Seah, G. C. Smith and M. T. Anthony: Surf. Interface Anal. 15, 293 (1990).

6) S. W. Gaarenstrocm : Appl. Surf. Sci. 26, 561 (1986).

7) C. Jansspn and P. Morgen : Surf. Sci. 233, 84 (1990).

8) K. Yoshihara, M. Yoshitake and the VAMASSCA Community: Surf. Interface Anal. 18, 724 (1992).

9) M.P. Seah and G.C. Smith : Surf. Interface Anal. 15, 309 (1990)

10) M. P. Seah and G. C. Smith: "Practical Surface Analysis: Auger and X-ray Photoelectron Spectroscopies" (ed. by D. Briggs and M. P. Seah, Wiley, Chichester, 1990) p. 537.

11）志水隆一，吉原一紘編：“実用オージェ電子分光 法”（共立出版，1989） p. 200.

12) W. A. Dench, L. B. Hazel, M. P. Seah and the VAMAS-SCA Community: Surf. Interface Anal. 13, 63 (1988).

13) C. J. Powell, N.E. Erickson and T. Jach : J. Vac. Sci. Technol. 20, 625 (1982).

14）刀根 薫: “BASIC”（培風館, 1981) p. 109. 